\title{
Detection of SARS-CoV-2 by the RT-qPCR in domestic cats
}

\author{
Detecção do SARS-CoV-2 a partir da técnica de RT-qPCR em gatos domésticos \\ Detección de SARS-CoV-2 mediante la técnica RT-qPCR en gatos domésticos
}

Received: 07/13/2021 | Reviewed: 07/18/2021 | Accept: 07/21/2021 | Published: 07/28/2021

Laila Natasha Santos Brandão

ORCID: https://orcid.org/0000-0001-7986-671X

Instituto Federal de Educação, Ciência e Tecnologia de Mato Grosso, Brazil

E-mail: 1.natasha.brandao@gmail.com

Daniela Paula Homochiski

ORCID: https://orcid.org/0000-0002-2373-0212

Instituto Federal de Educação, Ciência e Tecnologia de Mato Grosso, Brazil

E-mail: homochisnkidaniela@gmail.com

Letícia Barbosa de Oliveira

ORCID: https://orcid.org/0000-0003-0501-1967

Instituto Federal de Educação, Ciência e Tecnologia de Mato Grosso, Brazil

E-mail: letcia.oliveira@ifmt.edu.br

Rosimar Moro Soares de Oliveira

ORCID: https://orcid.org/0000-0003-1728-6298

Instituto Federal de Educação, Ciência e Tecnologia de Mato Grosso, Brazil E-mail: moro.rosimar@gmail.com

Sara Andreta Maciel

ORCID: https://orcid.org/0000-0002-5025-5816

Instituto Federal de Educação, Ciência e Tecnologia de Mato Grosso, Brazil

E-mail: saraandret@gmail.com

\begin{abstract}
SARS-Cov-2 has altered social behavior worldwide, causing drastic changes in the population's routine, its impacts have still been gradually perceived and several questions have arisen in the face of the pandemic, the possibility of interspecies transmission casts doubt on the participation of domestic animals in the epidemiology of the disease. The present study demonstrates the detection of the SARS-CoV-2 through RT-qPCR technique in unvaccinated domestic cats with free access outside the house, domiciled in Alta Floresta city (State of Mato Grosso, Brazil) with report of clinical respiratory manifestations and its possible transmission among individuals of the same species. Information like this is valuable and contributes to the understanding of the epidemiological chain of COVID-19 and may eventually assist in the establishment of future protocols for control and eradication programs, however the presence of positive animals needs to be carefully analysed and studied among specialists in order to avoid negative impacts on their relationship, owner and their pets, aiming to prevent unnecessary abandonment and sacrifices.
\end{abstract}

Keywords: Domestic cats; COVID-19; Epidemiological cycle.

\section{Resumo}

O SARS-Cov-2 alterou o comportamento social em todo o mundo, provocando mudanças drásticas na rotina da população, seus impactos ainda estão sendo gradativamente percebidos e diversos questionamentos surgiram diante a pandemia, entre eles, a possibilidade de transmissão interespécie levantando dúvidas a respeito da participação dos animais domésticos na cadeia epidemiológica da doença. O presente estudo demonstra a detecção do vírus SARS-CoV2 em gatos domésticos, não vacinados, domiciliados no município de Alta Floresta-Mato Grosso, com livre acesso à rua e com relato de manifestações clínicas de cunho respiratório através da técnica de RT-qPCR e sua possível transmissão entre indivíduos da mesma espécie. Informações como essa são valiosas e contribuem para a compreensão da cadeia epidemiológica da COVID-19 podendo eventualmente vir a auxiliar no estabelecimento de futuros protocolos para programas de controle e erradicação, todavia a presença de animais positivos precisa ser cuidadosamente analisada e estudada entre especialistas a fim de evitar impactos negativos na relação entre tutores e seus animais de estimação, visando evitar abandonos e sacrifícios.

Palavras-chave: Gatos domésticos; COVID-19; Ciclo epidemiológico.

\section{Resumen}

El SARS-Cov-2 cambió el comportamiento social en todo el mundo, provocando cambios drásticos en la rutina de la población, sus impactos aún se están notando paulatinamente y han surgido varias interrogantes ante la pandemia, entre ellas la posibilidad de transmisión interespecies, cuestionando el participación de animales domésticos. El presente 
estudio demuestra la detección del virus SARS-CoV-2 en gatos domésticos no vacunados domiciliados en el municipio de Alta Floresta - Mato Grosso, con libre acceso a la calle y reportando manifestaciones clínicas de carácter respiratorio mediante la técnica RT-qPCR , y su posible transmisión entre individuos de la misma especie. Información valiosa que contribuye al entendimiento de la cadena epidemiológica de COVID-19 y puede ayudar a establecer futuros protocolos para los programas de control y erradicación. Sin embargo, la presencia de animales positivos debe ser analizada cuidadosamente entre los expertos, a fin de evitar impactos negativos en la relación entre los tutores y sus mascotas, con el objetivo de evitar el abandono y los sacrificios.

Palabras clave: Gatos domésticos; COVID-19; Ciclo epidemiológico.

\section{Introduction}

Since its appearance, at the end of 2019, Coronavirus Disease (COVID-19) has taken global proportions, being quickly declared by the World Health Organization (WHO) as a pandemic viral disease. Severe changes in society's habits were necessary to adapt to the new reality, social isolation has been the most assertive measure to reduce the number of cases worldwide. The pandemic period increased the time in which pet owners stayed at their homes, due to the necessary social isolation, consequently increasing the time of close contact with their pets.

Contact with domestic animals, especially dogs and cats, is directly related to culture and social behavior of humans since the event of animal domestication. Considered more and more as family members, sharing the same domestic environments as their guardians (Jardim et al. 2020). The understanding about how these animals can be involved in potentially zoonotic pathologies can contribute to the development of future control strategies for biological agents, ensuring the safety of the domestic animals and their owners.

The possibility of zoonotic transmission of SARS-CoV-2 must be carefully speculated to avoid serious consequences, such as abandonment and sacrifices resulting from population misinformation (Deng et al. 2020). Evidence demonstrating that domestic animals can be infected is still scarce and the role of these animals as a source of virus infection even does not have enough scientific evidence to establish the participation in the epidemiological chain of these diseases (Deng et al. 2020; Shen et al. 2020; WSAVA 2020).

The present work aims to demonstrate and report the presence of the virus by the detection of SARS-Cov-2 in unvaccinated domestic cats (Felis catus) with free access outside the house, domiciled in Alta Floresta city (State of Mato Grosso, Brazil) with report of clinical respiratory manifestations and its possible transmission among individuals of the same species.

\section{Methodology}

The object of the study is a male feline mixed-breed, clinically healthy, adult (unknown age), unneutered and unvaccinated, with free access outside the house that remained missing for approximately a week and a half, without the tutor knowing its whereabouts. When it reappeared and returned to home, the owner observed clinical respiratory signs such as coughing, describing that the animal seemed to be choking, constant sneezing (a moment captured by filming) and the presence of fluid nasal secretion. The present animal has full access to all rooms in the house, however it remains outside at night. For the purposes of facilitating understanding and interpretation of the study, it will be referred to as CAT 1.

Since the animal owner is directly involved with the performance of diagnostic tests for COVID-19 in the municipality of Alta Floresta, as an intern, she requested authorization to perform the RT-qPCR test for SARS-COV-2 in her animals. The pet owner also has a female cat, mixed-breed, unvaccinated, unneutered, young adult female who lives directly with CAT 1, being mentioned in the text as CAT 2.

The first collection of material for analysis was carried out on April 16, four days after the cat's return to the residence, by its owner duly guided by a veterinarian, using a sterile swab. Samples was obtained from the cat's nasal region, seeking to obtain the greatest amount of secretion possible, the genetic material was extracted on the same day of collection, following the 
usual laboratory protocol using a commercial kit (PureLink ${ }^{\text {TM }}$ RNA Mini Kit-ThermoFisher®) and also the RT-qPCR test using Bio-Rad's CFX96 Touch ${ }^{\mathrm{TM}}$ Real-Time PCR Detection System. The reaction was carried out according to the manufacturers' protocols, using primers and probes that are manufactured at IDT® and Seegene ${ }^{\circledR}\left(2019-\right.$ nCoV RUO Kit and Allplex $^{\mathrm{TM}}$ SARSCoV-2 Assay respectively).

\section{Results and Discussion}

In the first sample obtained, it was possible to observe the positive test with amplification for the N, E and RdRP genes from the sets of primers and probes used, in view of the result, new samples were collected.

All samples were collected with sterile swabs and stored in sterile plastic falcon tubes and later stored at $-70^{\circ} \mathrm{C}$. To exclude the possibility of cross-contamination, resulting from the tutor that is also the handler of the samples, a nasopharyngeal sample was collected from her, obtaining a negative result for the test. From the cats, nasal and rectal swabs were collected the day after the first result, samples were also collected from cat 2 due to close contact with cat 1, positive in the first test, only the nasal samples collected from both were positive in the test time. Due to accessibility restrictions in the region and availability of immunological tests, only the rapid test (immunochromatography) to detect the antigen and antibodies can be performed, however, despite the control having worked, positivity for IGG and IGM was not observed.

The guardian of the animals was correctly vaccinated, receiving all the indicated doses of the adsorbed vaccine Covid19 (inactivated), CoronaVac, vaccine from Instituto Butantan against SARS-CoV-2 and the follow-up was carried out, via RTqPCR test, during the same period of study in the cats.

Cat 2 did not present any clinical signs, being clinically healthy at the beginning of the study. According to the tutor's report, the animal (cat 2) does not have the habit of being absent from the residence, having been under his supervision throughout the period that cat 1 was absent, having no contact with other animals or humans besides its guardian.

Both animals were periodically tested and over the weeks, cat 2 began to show the same clinical signs as cat 1 . Initially she had sporadic coughing and some sneezing that gradually became more frequent and intense, similar to what was observed in cat 1 , and also the presence of nasal secretion that gradually became more abundant. Cat 1 clinically recovered on May 12, 2021, although it was still positive for the RT-qPCR test, and on May 20, 2021 the test was negative.

To ensure the accuracy of the test results and their results, all samples were re-extracted and retested. Also fearing the region of the virus covered by the primers, two commercial kits (Allplex and IDT) were used, as well as a synthesized primer with sequences for the N1, N2, N3 regions. All results could be reproduced, showing no discrepancies from the previous ones. The SARS-Cov-2 results from viral mutations or recombinations that gave the virus the ability to infect humans, surpassing the animal-animal cycle (Lu et al.2020). According to a study, SARS-CoV-2 shares $96.2 \%$ of similarity with the coronavirus RaTG13 already identified in bats (Rhinolophus spp.), but had never been detected in another animal species (Zhou et al. 2020). Over the years, eventually, there have been reports of the ability of some species of coronaviruses to cross the interspecies barrier and become capable of infecting humans (Chan et al. 2013; Su et al. 2016; Wong et al. 2016).

Coronavirus term is used to refer to viruses of the Coronaviridae family, divided into two subfamilies, Letovirinae and Orthocoronavirinae, the second being divided into four genera: Alphacoronavirus, Betacoronavirus, Deltacoronavirus and Gammacoronavirus (ICTV, 2019), usually the alpha and beta groups infect mammals while delta and gamma generally infect fish and birds (WSAVA 2020), these viruses have already been observed in neurological, gastrointestinal, cardiovascular and respiratory diseases in several animal species, including humans.

The Feline Coronavirus (FCoV), from the Alphacoronavirus group, is responsible for feline infectious peritonitis, a severe and debilitating disease with no known cure (Addie \& Jarrett 2006), however there are no reports of natural interspecies 
transmission. However, the SARS-CoV-2 virus belongs to the Betacoronavirus genus, which is also composed of other viral species that cause respiratory diseases in humans. It is important to emphasize that there is no relationship between this and the Alphacoronaviruses, so the origin is not related to domestic animals (WHO 2020).

Previously, six coronaviruses capable of infecting humans have been described and two of them are associated with severe respiratory diseases, the Severe Acute Respiratory Syndrome virus (SARS-CoV), transmitted by a carnivorous mammal, masked palm civet (Paguma larvata) (Patou et al. 2009) and the Middle East Respiratory Syndrome Virus (MERS-CoV), in common, both have animals involved in their life cycle.

Particularly the newly discovered SARS-COV-2 drew worldwide attention after the onset of an acute disease, responsible for deaths in Wuhan Province, China in December 2019 (Zhou et al. 2020) that quickly spread across the Asian continent, reaching Europe and the Americas, being declared in March 2020 as a pandemic by the World Health Organization (WHO), given its speed of dissemination.

It is hypothesized that SARS-CoV-2 already existed and was restricted to wild reservoirs and that it possibly performed the interspecies leap (Ye et al. 2020). Contamination by SARS-CoV-2 occurs from droplets and aerosols propagated from the respiratory system of contaminated people, symptomatic or not, and may occur through direct contact or fomites (Leroy et al. 2020) in this way, domestic animals could become contaminated from positive owners.

Shi et al. (2020), experimentally analyzed viral replication in seven cats, infecting them intranasally with the virus, and found the presence of the agent in the respiratory and gastrointestinal tract of cats, supporting the possibility of replication in the species, corroborating the hypothesis that they are capable of spreading the virus. Clinical signs of diarrhea, emesis and dyspnea were described in a positive feline, who is suspected to have become infected due to direct contact with the infected guardian (Lopes et al. 2020).

Halfman et al. (2020), experimentally exposed healthy felines, without previous infection known as SARS-Cov-2, to felines inoculated with the virus and also found the possibility of transmission between cohabiting felines, corroborating reports that felines are capable of to eliminate the virus through aerial microparticles, however its infective possibility is still poorly understood (Goumenou et al. 2020).

SARS-Cov-2, as well as RNA viruses, have great genetic plasticity, resulting from the accumulation of mutations and recombinations (Deng et al. 2020). Unlike SARS and MERS, COVID-19 has low mortality and high morbidity, with a large number of asymptomatic individuals that facilitate its dissemination (Decaro et al. 2020). ACE2 receptors are present in several animal species and the virus enters the cell by binding to these receptors, further supporting the hypothesis of cross-species contamination.

\section{Final Considerations}

Does the increase of contact with domestic animals, resulting from the longer stay of guardians in the household due to the obligatory social isolation associated with close contact, place dogs and cats in the epidemiological cycle of the disease or not? The role of felines, particularly domestic cats as supposed silent intermediate hosts needs to be very clear. It is known that these are animals known to be more agile and more difficult to maintain in a restricted environment being common, even with guardians more attentive to, eventual escapes put cats in contact with a greater number of potential fomites and hosts. Even without proper proof that animals are capable of transmitting the virus to other animals or humans it is important that those responsible for the infection maintain the correct isolation for the protection of animals and public health since the breakdown of agent transmission chain is one of the best mechanisms for controlling pandemics. 


\section{References}

Addie, D. D. \& Jarrett, O. (2006). Feline Coronavirus Infections. In: Grene CE. Infectious diseases of the dog and the cat. St.Louis: Saunders Elsevier, p.88-102.

Chan, J. F., To, K. K. W., Tse, H., Jin, D. Y. \& Yuen, K. Y. (2013). Interspecies transmission and emergence of novel viruses: lessons from bats and birds. Trends Microbiol, 21:544-555.

Decaro, N., Martella, V., Saif, L.J. \& Buonavoglia, C. (2020). COVID-19 from veterinary medicine and one health perspectives: what animal coronaviruses have taught us. Res Vet Sci, 131:21-23.

Deng, J., Yipeng, J., Liu, Y., Sun, J., Hao, L., Bai, J., Huang, T., Lin, D. \& Jin, Y. (2020). Serological survey of SARS-COV-2 for experimental, domestic, companion and wild animals excludes intermediate hosts of 35 different species of animals. Transbound and Emerg Dis, 67(4):745-1749.

Goumenou, M., Spandidos, D. A. \& Tsatsakis, A. (2020). Possibility of transmission through dogs being a contributing factor to the extreme Covid-19 outbreak in North Italy. Mol Med Rep, 21(6):2293-2295.

Halfman, P. J., Hatta, M., Chiba, S., Maemura, T., Fan, S., Takeda, M., Kinoshita, N., Hattori, S.I., Sakai-Tagawa, Y., Iwatsuki-Horimoto, K., Imai, M. \& Kawaoka, Y. (2020). Transmission of SARS-CoV-2 in Domestic Cats. N. Eng. J. Med, 383(6):592-594.

International Committee on Taxonomy of Viruses. MasterSpecies List (2019) (MSL34) - Update.

Jardim, A. M., Lorenzetti, E. \& Grecco, F. (2020). Covid-19 x Cães e Gatos. Ensaios, 24(4):325-328.

Leroy, E. M., Gouilh, M. A. \& Brugere-Picoux, J. (2020). The risk of SARS-CoV-2 transmission to pets and other wild and domestic animals strongly mandates a one - health strategy to control the COVID-19 pandemic. One Health, (10):100133.

Lopes, O. F. M., Gomes, N. R. S., Freitas, D. R. J. \& Evangelista, L. S. M. (2020). COVID-19 e os animais domésticos: há alguma evidência de relação entre eles? J Health Biol Sci, 8(1):1-6.

Lu, R., Zhao, X., Li, J., Niu, P., Yang, B., Wu, H., Wang, W., Song, H., Huang, B., Zhu, N., Bi, Y., Ma, X., Zhan, F., Wang, L., Hu, T., Zhou, H., Hu, Z., Zhou, W., Zhao, L., Chen, J., Meng, Y., Wang, J., Lin, Y., Yuan, J., Xie, Z., Ma, J., Liu, W. J., Wang, D., Xu, W., Holmes, E. C., Gao, G. F., Wu, G., Chen, W., Shi, W. \& Tan, W. (2020). Genomic characterization and epidemiology of 2019 novel coronavirus: implications for virus origins and receptor binding. Lancet, 395(10224):565-574.

Patou, M.L., Chen, J., Cosson, L., Andersen, D.H., Cruaud, C., Couloux, A., Randi, E., Zhang, S. \& Veron, G. (2009). Low genetic diversity in the masked palm civet Paguma larvata (Viverridae). J Zool n.278, 3:218-230.

Shen, M., Liu, C., Xu, R., Ruan, Z., Zhao, S., Zhang, H., Wang, W., Huang, X., Yang, L., Tang, Y., Yang, T. \& Jia, X. (2020). Sars-CoV-2 infection of cats and dogs? Preprints.

Shi, J., Wen, Z., Zhong, G., Yang, H., Wang, C., Huang, B., Liu, R., He, X., Shuai, L., Sun, Z., Zhao, Y., Liu, P., Liang, L., Cui, P., Wang, J., Zhang, X., Guan, Y., Tan, W., Wu, G., Chen, H. \& Bu, Z. (2020). Susceptibility of ferrets, cats, dogs, and other domesticated animals to SARS-coronavirus 2. Science, 368(6494):1016-1020.

Su, S., Wong, G., Shi, W., Liu, J., Lai, A.C.K., Zhou, J., Liu, W., Bi, Y. \& Gao, G.F. (2016). Epidemiology, genetic recombination, and pathogenesis of coronaviruses. Trends Microbiol, 24:490-502.

Wong, L. Y. R., Lui, P.Y. \& Jin, D.Y. (2016). A molecular arms race between host innate antiviral response and emerging human coronaviruses. Virol. Sinica 31(1):12-23.

World Health Organization. Director-General's opening remarks at the media briefing on COVID-19-11 March 2020.

World Small Animal Veterinary Association. The New Coronavirus and Companion Animals - Advice for WSAVA Members (2020). Canadá: WSAVA.

Ye, Z. W., Yuan, S., Yuen, K.S., Fung, S. Y., Chan, C. P. \& Jin, D. Y. (2020). Zoonotic origins of human coronaviruses. Int J Bio Scie, $16(10): 1686-1697$.

Zhou, P., Yang, X.L., Wang, X.G., Hu, B., Zhang, L., Si, H.R., Zhu, Y., Li, B., Huang, C.L., Chen, J., Luo, Y., Guo, H., Jiang, R.D., Liu, M.Q., Chen, Y., Shen, X.R., Wang, X., Zheng, X.S., Zhao, K., Chen, Q.J., Deng, F., Liu, L.L., Yan, B., Zhan, F.X., Wang, Y.Y., Xiao, G.F. \& Shi, Z.L. (2020). A pneumonia outbreak associated with a new coronavirus of probable bat origin. Nature, 579(7798):270-273. 